\title{
Pembuatan Sistem Bank Sampah Online pada Kelurahan Serua
}

\author{
Hata Maulana ${ }^{1}$, Risna Sari ${ }^{2}$, Euis O. ${ }^{3}$, Iklima Ermis I. ${ }^{4}$, Shinta ${ }^{5}$. \\ 1,2,3,4,5 Program Studi Teknik Informatika, Jurusan Teknik Informatika dan Komputer \\ Jl. Prof. G.A. Sywabessy Kampus UI Depok \\ e-mail: hata.maulana@tik.pnj.ac.id, risna.sari@tik.pnj.ac.id, euis.oktavianti@tik.pnj.ac.id, \\ iklimaermis.ismail@tik.pnj.ac.id, shinta.oktaviana@tik.pnj.ac.id.
}

\begin{abstract}
Abstrak
Teknologi Informasi juga dapat didekatkan sebagai solusi permasalahan yang terjadi pada aspek kehidupan sosial masyarakat. Salah satu masalah sosial yang masih memerlukan penanganan serius adalah pengelolaan sampah limbah rumah tangga, secara spesifik adalah pada sampah anorganik. Bank sampah merupakan solusi yang sedang dikembangkan oleh pemerintah untuk menekan peningkatan sampah anorganik. Kelurahan Serua, Kecamatan Bojongsari, Depok merupakan salah satu lembaga pemerintahan di lingkungan Kota Depok menghadapi permasalahan pengelolaan sampah anorganik. Dalam hal ini secara khusus pada wilayah Kelurahan Serua Bojongsari Depok, untuk mendukung program pemerintah Kota Depok menuju cyber city, maka berencana menyelesaikan masalah pengelolaan sampah anorganik dengan pendekatan TI. Sebuah sistem Bank Sampah online diterapkan sebagai alternatif pelayanan pemerintah dalam mengelola sampah anorganik dilingkungan masyarakat sekitar. Sistem Bank Sampah online memiliki fitur yang memudahkan masyarakat dalam menyukseskan program pemerintah ini. Beberapa fiturnya antara lain penukaran saldo ke pulsa listrik atau Handphone, melihat saldo, dan transfer saldo ke sesama pengguna. Sistem juga dirancang dapat dibuka pada browser smartphone. Pembuatan dan implementasi sistem ini dalam program pengabdian masyarakat Program Studi Teknik Informatika Politeknik Negeri Jakarta. Implementasi sistem ditujukan pada masyarakat setempat dalam bentuk pelatihan di awal serta dilanjutkan dengan monitoring sebagai kontrol pelaksanaan program ini.
\end{abstract}

Kata Kunci- Bank Sampah online, Berbasis web, Grogol, Cyber city.

\begin{abstract}
Information technology can also be brought together as a solution to problems that occur in the aspects of social life. One social problem that still requires serious handling is the management of household waste, specifically inorganic waste. Waste banks are a solution that is being developed by the government to reduce the increase in inorganic waste. Serua Village, Bojongsari District, Depok is one of the government institutions in Depok City facing the problem of inorganic waste management. In this case specifically in the area of Serua Bojongsari Depok Subdistrict, to support the Depok City government program towards cyber city, it plans to solve the problem of inorganic waste management using the IT approach. An online Waste Bank system is applied as an alternative government service in managing inorganic waste within the surrounding community. The online Waste Bank System has features that make it easier for people to succeed in this government program. Some features include exchanging balances to electric pulses or mobile phones, viewing balances, and transferring balances to fellow users. The system is also designed to be opened on a smartphone browser. The making and implementation of this system in the community service program Informatics Engineering Study Program of the Jakarta State Polytechnic. The implementation of the system was aimed at the local community in the form of training at the beginning and continued with monitoring as control of the implementation of this program.
\end{abstract}

Keywords- Online Waste Bank, Web Based, Grogol, Cyber city.

\section{PENDAHULUAN}


satunya kelurahan Grogol yang berada diwilayah kecamatan Limo memiliki program dalam mendukung Kota Depok menjadi cybercity. Dalam hal ini berkaitan pada masalah sosial masyarakat yang terjadi adalah pengelolaan sampah, khususnya sampah anorganik. Sampah anorganik menjadi penyumbang produksi sampah Kota Depok yang mencapai 1250 Ton per hari (Republika.co.id). Pemerintah Kota Depok melalui Walikotanya K.H. Muhammad Idris A. Shomad menegaskan bahwa Kota Depok menuju menjadi Kota Bebas Sampah atau Zero Waste City. Menurut Kepala Dinas Kebersihan dan Pertamanan (DKP) Kota Depok dari total produksi sampah, jumlah sampah anorganik mencapai 40 persennya.

Menurut Kepala DKP Kota Depok (Republika.co.id) "Setiap satu orang berkontribusi pada kontribusi sampah sebesar 0,5 hingga $0,7 \mathrm{~kg}$ per hari”. Hal ini menggugah kita sebagai warga Depok untuk ikut berpartisipasi aktif dalam permasalahan sampah. Dari pernyataan Kepala DKP Kota Depok tersebut, Politeknik Negeri Jakarta yang berdomisili di Kota Depok melalui Prodi Teknik Informatika (TI) ikut memiliki peran memberikan solusi. Prodi TI dalam hal ini melalui program pengabdian kepada masyarakat, menyasar kepada kelurahan Serua, kecamatan Bojongsari, Depok beserta kelompok Ibu-ibu rumah tangganya. Pembuatan sistem Bank Sampah online berbasis web ini memiliki sejumlah fitur yang menyesuaikan kebutuhan warga, yakni melihat Saldo tabungan sampah, melakukan transfer Saldo ke sesama nasabah bank sampah, menukar Saldo dengan Pulsa Listrik dan sejumlah fitur pelengkap lainnya. Sistem Bank Sampah online ini selain berbasis web juga bersifat responsive yaitu dapat dijalankan dengan browser smartphone.

Pengelolaan sampah dengan fasilitas Bank Sampah merupakan alternatif solusi untuk menekan angka sampah anorganik yang mencapai 40\%. Selain itu juga mengikuti perkembangan teknologi yang saat ini telah merubah perilaku masyarakat Indonesia. Pada penerapannya sistem ini membutuhkan pengelola, dalam hal ini staf pegawai kelurahan Serua. Melalui Sistem ini diharapkan warga Depok, khususnya kelurahan Serua dapat menjaga lingkungannya dan mendapatkan manfaat untuk kebutuhan sehari-hari.

Mengacu latar belakang masalah, permasalahan yang dihadapi Kelurahan Serua adalah sebagai berikut, Pihak Kelurahan mengklaim telah memiliki Bank Sampah binaan, namun terkendala operasional dan peminatan warganya, Bank sampah belum terkelola dengan baik dan transparan, dan Bentuk pengelolaan yang monoton tidak memberikan daya tarik terhadap warga calon nasabahnya.

Tujuan dari kegiatan pengabdian kepada masyarakat ini adalah membuat dan mensosialisasikan sistem bank sampah online pada kelurahan Serua, kecamatan Bojongsari, Depok.

\section{METODE PELAKSANAAN}

Metode yang digunakan dalam kegiatan pengabdian kepada masyarakat ini adalah pembuatan sistem sesuai kebutuhan dan melaksanakan sosialisasi/pelatihan penggunaan sistem bank sampah online (Warga Mandiri). Serta menyelenggarakan pendampingan pemanfaatan sistem Warga Mandiri pada kelurahan Serua kota Depok. Peserta adalah seluruh warga dan staf pegawai kelurahan Serua, untuk mendapatkan sosialisasi/pelatihan penggunaan sistem Warga Mandiri, dengan fasilitas Laptop, Modem dan Buku pedoman tutorial penggunaan sistem Warga Mandiri. Selain itu akan diberikan pendampingan kepada staf admin kelurahan Serua untuk mengelola sistem Warga Mandiri. Evaluasi dilakukan dengan menggunakan metode kuisoner.

\section{HASIL DAN PEMBAHASAN}

Jenis kegiatan pengabdian kepada masyarakat berbasis Iptek bagi masyarakat (IbM) yang telah dilaksanakan berupa pembuatan sistem dan sosialisasi penggunaan sistem Warga Mandiri. Kegiatan tersebut diselenggarakan sebagai bentuk partisipasi civitas akademika PNJ dalam pemberdayaan masyarakat, khususnya para warga kelurahan Serua.

Evaluasi peserta pelatihan dan sosialisasi sistem Warga Mandiri dalam hal ini menggunakan kuesioner evaluasi pelatihan. Kuesioner disebarkan kepada 22 peserta (nama dan tanda tangan peserta terlampir) setelah kegiatan pelatihan dilaksanakan. Berikut adalah hasil kuesioner evaluasi pelatihan tersebut, 


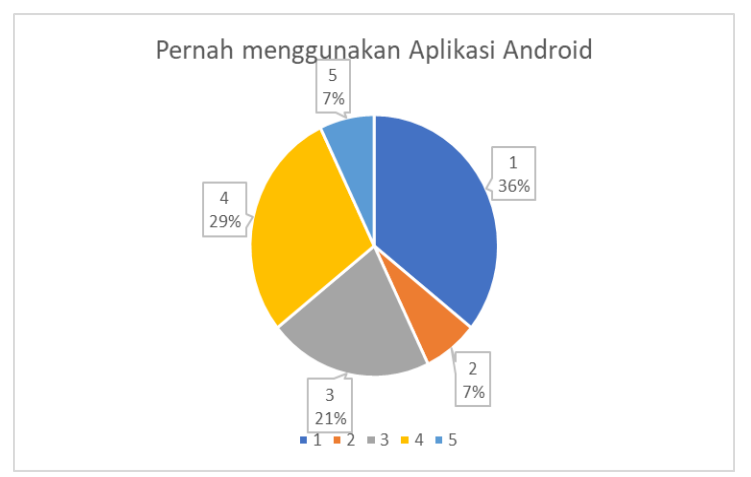

Gambar 1. Hasil Jawaban

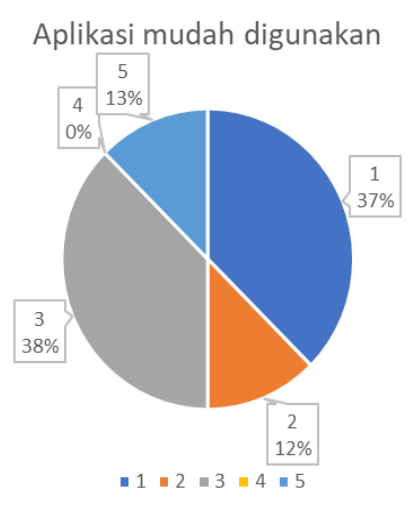

Gambar 2. Hasil Jawaban

Tertarik Aktif dalam Program Bank Sampah Online

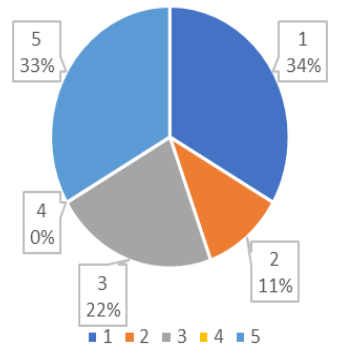

Gambar 3. Hasil Jawaban

Gambar 1 menunjukan bahwa dominasi peserta pelatihan, sebanyak $36 \%$ telah pernah menggunakan aplikasi android. Hal ini membantu pemateri lebih mudah menyampaikan tahapan penggunaan sistem bank sampah online dalam versi mobile. Selain itu peserta juga antusias bertanya dengan pemahaman penggunaan aplikasi android sebelumnya.

Gambar 2 menunjukan sebanyak 37\% sangat setuju bahwa aplikasi mudah digunakan oleh peserta pelatihan. Hal ini menunjukan tingkat keberlanjutan sistem bank sampah online digunakan oleh peserta pelatihan sangat tinggi, dengan tanggapan mudahnya penggunaan sistem.

Gambar 3 memperlihatkan sebanyak 34\% peserta tertarik aktif dalam program bank sampah online. dengan hal ini penerapan sistem bank sampah online pada kelurahan serua bojongsari depok ini sangat tepat dan sesuai untuk dapat digunakan oleh warga sekitar yang sangat tertarik pada program bank sampah.

\section{PENUTUP}

IbM berbasis Prodi melalui Kegiatan pembuatan dan pelatihan/sosialisasi penggunaan sistem Warga Mandiri. Selain itu juga menambah wawasan tentang teknologi informatika khususnya dibidang Teknik Informatika. Admin yang merupakan staf pegawai Kelurahan Serua Bojongsari Depok, selanjutnya dapat menggunakan sistem Warga Mandiri dan mengelola harga, nasabah bank sampah kelurahan Serua. Sedangkan warga sebagai nasabah dapat menggunakan sistem bank sampah online ini dalam transaksi penukaran saldo sampah ke pulsa handphone maupun token listrik pribadi.

Saran untuk kelanjutan kegiatan adalah diperluasnya mitra kegiatan melalui bantuan Pemerintah Kota Depok khususnya instansi dinas lingkungan hidup dan kebersihan (DLHK) kota Depok memberdayakan sistem serupa untuk seluruh kelurahan di wilayah Kota Depok. Selain itu kontribusi mitra baik dalam bentuk materi maupun fasilitas pelatihan sangat diharapkan untuk kelancaran kegiatan, seperti asosiasi bank sampah seluruh kota Depok.

\section{UCAPAN TERIMA KASIH}

Terimakasih atas ijin dan partisipasi warga kelurahan Serua, Bojongsari, Depok, Khususnya kepada Bapak Lurah Serua dan jajarannya yang telah membantu secara langsung.

\section{DAFTAR PUSTAKA}

[1] Dinas Lingkungan Hidup dan Kebersihan (DLHK) Kota Depok, "Data Sampah Kota Depok 2018", Depok, 2018.

[2] Hendrawan, P. (2012, April 15). TEMPO.CO. Retrieved April 27, 2016, from m.tempo.co: https://m.tempo.co/read/news/2012/04/15 /063397147/indonesia-hasilkan-625-jutaliter-sampah-sehari 
[3] Kementerian Lingkungan Hidup RI. (2012, November 2). Buku Profil Bank Sampah Indonesia 2012. Jakarta, DKI Jakarta, Indonesia.

[4] Portal Resmi Pemerintah Kota Depok.

[5] Pedoman Penelitian dan Pengabdian Masyarakat XI, Direktorat Riset dan
Pengabdian kepada Masyarakat (DRPM), Kemeristekdikti RI.

[6] P3M, P. P. (2016). Rencana Strategis (Renstra) Penelitian Politeknik Negeri Jakarta. Depok.

[7] Republica.co.id. 